\title{
Determinants of Thai Baht Exchange Rate and Asian Currencies Exchange Rate
}

\author{
Paitoon Kraipornsak ${ }^{1}$ \\ ${ }^{1}$ Faculty of Economics, Chulalongkorn University, Bangkok, Thailand \\ Correspondence: Paitoon Kraipornsak, Faculty of Economics, Chulalongkorn University, Bangkok 10330, Thailand. \\ E-mail: kpaitoon@chula.ac.th
}

Received: July 10, 2020

doi:10.5430/rwe.v11n5p1

\author{
Accepted: August 18, 2020 \\ Online Published: September 3, 2020 \\ URL: https://doi.org/10.5430/rwe.v11n5p1
}

\begin{abstract}
The study hypothesises that the exchange rate is a random walk series. Besides, the study incorporates main macroeconomic factors as a structural exchange rate determination. The Vector Error Correction Model (VECM) is applied in the model estimation for Thai baht. Moreover, the panel data model of the Asian exchange rate is estimated and analysed. The exchange rate of Thai baht is found to be a random walk process. The long-run equilibrium of the estimated cointegrating relation indicates all coefficients of the determining factors are statistically significant. An increase in the real interest rate and the foreign reserve has significant appreciation effects on the Thai baht. An increase in the income per capita has a significant depreciation effect on the Thai baht. External debt causes a depreciation in the Thai baht. The most substantial impact on the value of Thai baht is the income per capita. It follows by the foreign reserve, the real interest rate, and the external debt, respectively. During 2017 and 2018, the estimated exchange rate is appreciated by 4.21 per cent that is close to the actual appreciated value. The estimated Asian model is found consistent with the model of the Thai baht. The highest impact on the local Asian currencies is the income per capita. It follows by the foreign reserve and the real interest rate, respectively, with both quite close by their sizes. However, the foreign reserve has a more appreciated influence than that of the real interest rate for Thai baht.
\end{abstract}

Keywords: exchange rate, random walk, VECM, Thai baht, Asian currencies, real deposit interest rate, foreign reserve, income per capita, external debt

\section{Introduction}

Determinants of exchange rate behaviour are one of the most crucial issues in economics. The exchange rate reflects the relative prices of local products relative to foreign products. It can be an essential part in determining countries' price competitiveness. The exchange rate is, therefore, a key factor of economic development, especially in developing countries as these countries rely on exports as a significant source of growth.

Several factors can influence and determine how much the relative value of a local currency to a foreign currency (the exchange rate) is. The exchange rate of a local currency to a foreign currency is principally determined by its demand for and supply of the foreign currency. Factors that increase the demand for dollar (such as higher imports) implies an increase in demand for the dollar thus increase in the dollar value. In the opposite direction, if a country can earn a lot of dollars such as an increase in demand for exports, the country receives much more supply of dollar so the value of the dollar will decrease or the local currency will appreciate.

The exchange rate plays a crucial role in international balance by changing the local currency value in response to a change in economic conditions. The local currency will become stronger if the country has a surplus balance of payment. The higher relative value of the local currency will cause lower prices of imports and higher costs of exports that can restore the country's balance of payment.

Nevertheless, some factors under an economic condition can cause the movement of the exchange rate to be too much or too little. A particular situation can create an undesirable consequence in the economy. There may be a specific case where mismanagement of one or more economic factors that lead to an unwanted change in the value of the local currency. In such the case, policymakers may be in need to manage factors that influence the exchange rate to change properly into a desirable condition.

Long after the year 2000, Thailand's local currency has been a rather strong currency relative to most currencies. 
Figure 1 shows that over the years, the value of Thai baht has appreciated for decades since after the Asian financial crisis during 1997-1999. Over many recent years, all significant macroeconomic variables in Thailand, such as GDP growth (GDPGR), inflation (CPIGR), and deposit interest rate (DEPRT) have shown quite an unhealthy situation. Under the worsening macroeconomic condition, the trend of the exchange rate (OER) of the Thai baht expressed an appreciation of its value. An interesting question is why the Thai baht has been relatively stronger even though the Thai general macroeconomic conditions have been quite unhealthy, and the GDP growth has recently been rather flat. Thailand's GDP growth had mostly been over 6 per cent before the Asian financial crisis.

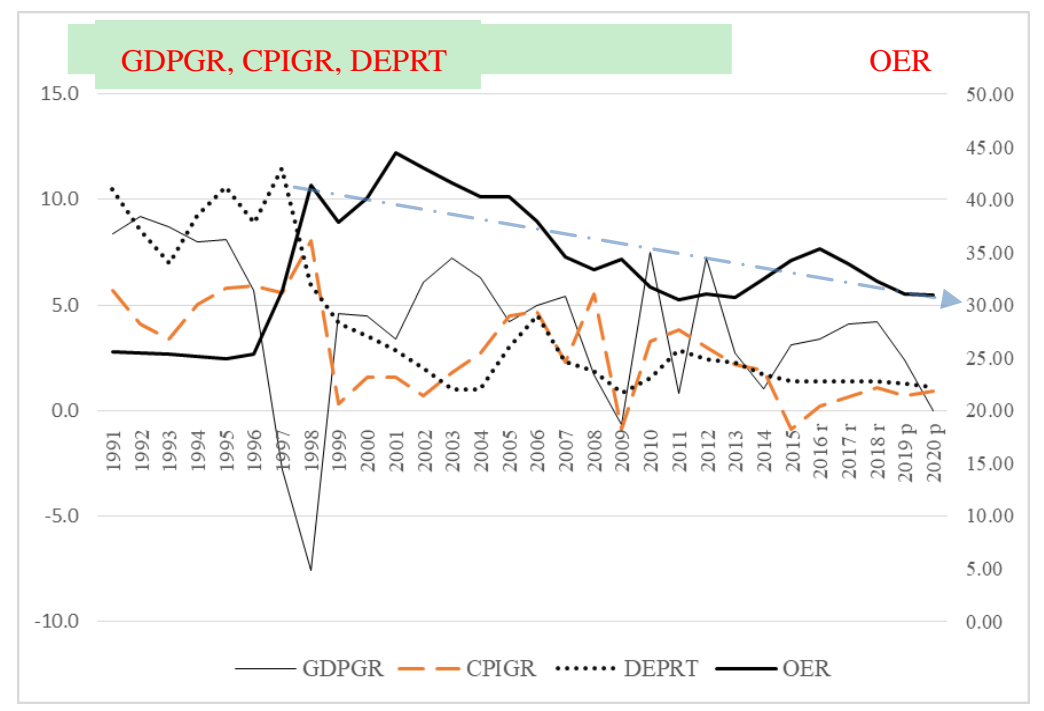

Figure 1. Official exchange rate of Thai Baht and major macroeconomic conditions

Source: Data from the Bank of Thailand

The exchange rate of Thai baht to the other major foreign currencies has been lowering or baht appreciation (Figure 2). The figure shows the exchange rate of the Thai baht with the four significant currencies measured in Thai baht per the other foreign currencies: U.S. dollar, E.U. dollar, Japanese yen, and the Singapore dollar. However, the Thai economic growth has been growing relatively small in recent years since after the financial crisis in 2000.

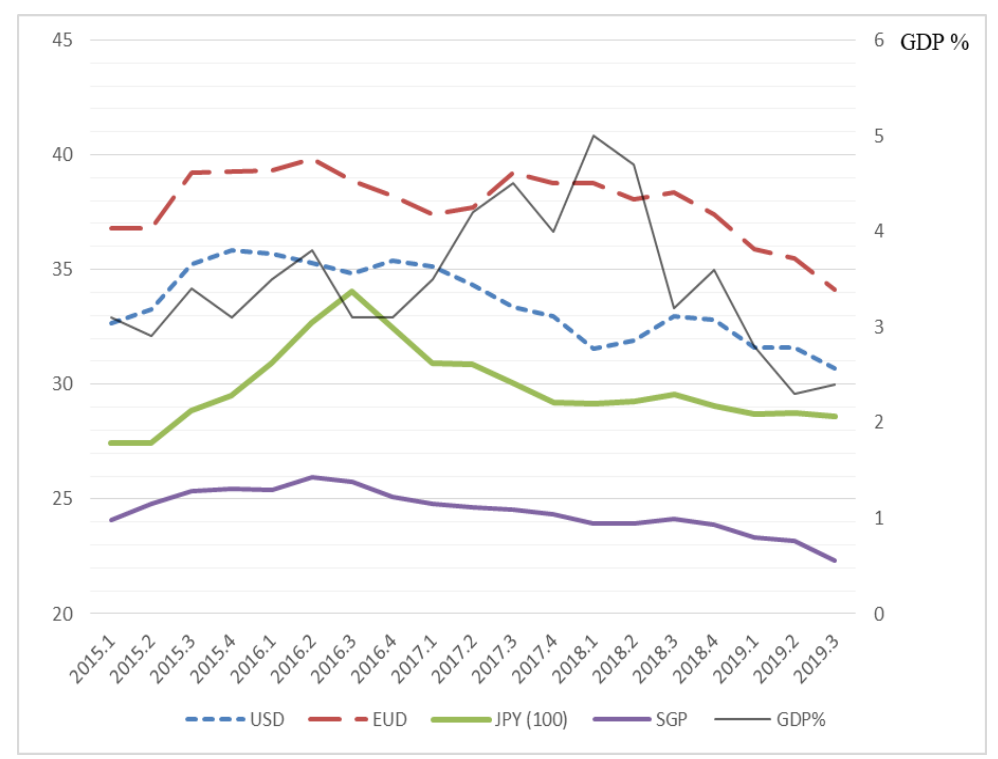

Figure 2. Exchange rate of Thai Baht to major currencies

Source: Data from the Bank of Thailand 
Thailand is one of the developing countries where the economy heavily depends on exports. The higher value of Thai baht (baht appreciation) is thus worsening the economy inevitably. Exports account for about 65-70 per cent of GDP in Thailand over a long period. In 2019, the Thai baht was seen to be too strong expressed by foreign financial experts such as economists at Dutch Bank ING and DBS Singapore (CNBC, 2019). The relatively strong Thai baht was considered being in improper time for the weakening economy of Thailand.

An exchange rate behaviour model is well acknowledged to be unsolved research issues. It is critical to empirically investigate in details of what are the significant factors that determine the value of the Thai baht. Consequently, the policymakers can implement the right policy measure to keep the Thai baht value to be in an appropriate range to help stimulate export price competitiveness of the export of Thailand. Although there is no specific exchange rate target in some countries in ASEAN, it does not imply that there is no intervention in the currency market. Several countries reveal some interventions to control the volatility of the exchange rates at least in the short run (Klyuev, \& Dao, 2016). For Thailand, the Bank of Thailand states in the Bank of Thailand Act that the stabilisation of the payments system is a primary responsibility of the bank.

As it realises that the exchange rate naturally is quite volatile, the dynamic time series model in the form of Vector Error Correction is, therefore, an appropriate tool of analysis. The study empirically examines the determinants of the exchange rate in the short run and the long run. The structure of exchange rate determination will also be discussed and compared with the model of the Asian currencies in panel data analysis.

\section{Review of the Literature}

On earlier models of exchange rate determination in an open economy, international balance and external balance simultaneously determine the relationship between the exchange rate and the balance of payment in the economy (Meade, 1951; cited in Castillo, 2002, P: 257). Mundell (1968) found out that the balance of payment position, in the long run, is essential to determine the exchange rate. To sustain the balance of payment, it requires a significant amount of foreign reserves when the countries are in a deficit balance. On the contrary, states of a surplus balance of payment require unreciprocated export of capital. Role of the foreign reserve is therefore essential in determining the exchange rate.

Even though many economists pay attention to analysing exchange rate behaviour, there has been the unclear success of determinants of exchange rates empirically (Chinn, 2003). The study listed main factors affecting the exchange rates; those are productivity changes, purchasing power parity, different market characteristics, and interest rate and expectations. Apart from the analysis of the exchange rate behaviour, a concern question is whether the exchange rate is predictable. The study points out that no other model can consistently outperform a random walk of the time series model.

Mundell (1968) began discussion from a closed economy and be a more open economy. The study focused on the theoretical and practical implication of capital mobility. Once a country has a free movement of capital, so it means all types of capital are perfect substitutes. Exchange rate margin does not exist. Any budget deficit is financed by public debt. A reduction in cash balances will fund an excessive private investment over saving. A decrease in foreign reserves finances a deficit balance of trade. The market of foreign currency is in equilibrium means increased reserves is equal to the rate that the central bank wants to buy.

The monetary approach can explain the exchange rate using the dynamic method. The exchange rate was found to be volatile, especially under the floating exchange rate regime (Cumby \& Obstfeld, 1984; Frenkel, 1981). Flexible exchange rate, along with greater mobility of capital, can increase exchange rate volatility. International money demand can describe moving of exchange rate in responding to relative prices of any two countries in consequence of the relative demand for and supply of money in both countries.

Dornbusch (1976) developed an exchange rate dynamics model with a rational expectation to observe a significant exchange rate fluctuations. The national price levels are constrained, and so is slowly adjusted. The model accounts for the deviation from the Purchasing Power Parity (PPP) in the short run in responding to any economic and political information. The PPP is thus a long run existence.

The PPP examines exchange rate in connecting with a price. The consideration of the PPP approach is in two forms: absolute and relative forms (del Castillo, 2002). In the absolute PPP, the nominal exchange rate is determined by comparable prices between domestic and foreign prices. The relative PPP approach gives a constant parameter accounting for transportation costs and impediments to trade to be the weight of the national price level in the ratio to the foreign price level. This link between the exchange rate and the price is in the light of changes in the long-run exchange rate. 
The PPP hypothesis is argued for an unrealistic assumption since it is based on the law of one price. The law of one price will no longer hold when the trade contains transportation cost and some barrier to trade. The real exchange rate has been evidence of being fluctuated over time. Many factors can create relative prices to change in the short run. In the case of cross country analysis, structural differences such as productivity, consumer preferences, factor endowment and production function can cause different relative prices of tradable and non-tradable goods.

Under the Portfolio-Balance Model and flexible exchange rate, the exchange rate is determined by the monetary framework saying that stocks of alternative assets affect various rates of return and therefore changes in demand for money (Frenkel \& Mussa, 1985). The Portfolio-Balance Models expresses the link between the exchange rate and the current account. The current account can change the statements in the long-run real exchange rate. In the end, a country can accumulate many foreign reserves once the country is at a surplus current account position.

The exchange rate dynamic can also be examined empirically by using econometric time series models to provide an in-depth analysis. Apart from the demand for and supply of money, major portfolio choice factors including incomes, rates of return on money, and expectation in the asset market can also determine the exchange rate. This concept is the asset markets approach to the dynamic exchange rate determination.

Meese \& Rogoff (1983) compare various structural exchange rate and time-series exchange rate models for the out of sample forecasts. Previous studies were done based on the in-sample data fit. The study focuses on the current spot exchange rate and employs the methods of the univariate time series analysis and the vector autoregression analysis in the estimation of the model. The study examined the models for the dollar-pound, dollar-mark, dollar-yen, and the trade-weighted dollar exchange rates. The structural models in types of flexible price, a sticky-price, including the current account, as well as time series models, are estimated and compared the out of sample forecasting accuracy.

Froot \& Rogoff (1994) study the real exchange rates using the long period data and found the real exchange rate is exhibit like a random walk, having a trend to move revert towards their mean. The study found that the random walk without drift model is the well approximated for the country exchange rates. The various estimations using the univariate time series model, the vector autoregression model, and those structural model of exchange rate are also found to perform similarly.

On the contrary, Hwang (2003) tested the Dornbusch-Frenkel monetary structural model and found that the model with modified money demand could dominate the random walk model. Hwang estimated the Dornbusch and Frankel sticky-price exchange rate model using Johansen's multivariate cointegration analysis and found that there exists a long-run relationship between exchange rate and economic fundamental. There exists up to three long-run cointegrating vectors in the test. When he modified the model with money demand function, the Dornbusch-Frenkel model based on the error correction models can give an accuracy forecasted exchange rates at every forecasting prospect except the 12 months.

Cheung, Chinn, \& Pascual (2005) re-assessed prediction of the exchange rate of those monetary and Portfolio-Balance models. The study used a broad set of models to examine their model performances covering interest rate parity, productivity hypothesis, and behavioural exchange rate equilibrium models. The finding cannot confirm any possible specification of the model to do better than the others. Some models do well or successful in some basis. More importantly, a specific currency combination model can work well in a particular period of study but cannot work well in another period.

Under a fixed exchange rate system, its official nominal exchange rate is corresponding to a balance of payment. The exchange rate is, however, rather difficult to see a clear relationship in the short run for the floating exchange rate system (Makin, 1984). The study viewed the exchange rate from a monetary perspective connecting the exchange rate with price levels through monetary policy. The floating exchange rate can be considered as an endogenous factor corresponding with a particular monetary condition thus the rate does not have a clear relationship with the price level and balance of payment especially in the short run. Therefore, factors that cause the exchange rate to fluctuate will be less obvious than it does in the long term. To handle the short-run fluctuation and long-run equilibrium, the dynamic model of the type of Vector Error Correction Model can be an appropriate method.

Tease (1990) examined the behaviour of the balance of payments into two approaches: an approach based on imports, exports, expenditure, and relative prices and other procedure based on a reflection of domestic investment and saving. Fluctuation in the current account is caused by terms of trade, savings and investment, foreign capital flows and monetary policy. The study found there is cointegration between nominal imports and exports. Alternatively saying real imports is cointegrated with real exports and terms of trade. This finding implies that a permanent change in 
terms of trade can have little impact on the current account.

Regarding saving and investment, saving-investment imbalances and so imbalances in current account cannot be too excessive due to limited capital flow. Size of current account deficits was limited by the presence of an increase in capital mobility over time. The saving-investment imbalance is constrained by a limit of access to foreign capital, causing lower or higher investment or saving.

Many empirical studies employed various methods and tried to explain the exchange rate and macroeconomic fundamentals. Salim \& Shi (2019) analysed a cointegration of the exchange rate and macroeconomic fundamentals of Indonesian rupiah as a case study. They realised that the exchange rate has its determinants in some countries. The modified model of the nominal exchange rate, including trade balance to represent the sticky-price asset model, is estimated using time series econometrics analysis. A type of Autoregressive Distribution Lag model of both linear and non-linear relations are used in the estimations. Major included explanatory variables are the difference in domestic and foreign money supply, the difference in domestic and foreign output, the difference in domestic and foreign interest rate, the difference in domestic, and the foreign inflation rate as well as the trade balance. The statistical tests indicate that there is a high correlation between the exchange rate and its fundamental macroeconomic variables both in the short-run and in the long-run for each currency pairs of five most trading partners of Indonesia.

Abhyankar, Sarno, \& Valente (2005) re-examines the robustness of the Meese and Rogoff puzzle results that the structural models of exchange rate based on monetary fundamentals produced no better out-of-sample forecasts of the nominal exchange rate than a random walk model. Their study employs several econometrics techniques to take account for possible problem including small sample bias and near integrated regressors in the predictive regression. The study focused on a metric of the economic value of the exchange rate forecasts to an investor using a fundamental monetary base. Investors are assumed to face the problem of choosing between two identical assets except for the currency of denomination. The study found that exchange rate predictability using the monetary fundamental model yield optimal weights to the foreign asset that can be very much different from the optimal weights of a random walk model.

A family of parametric estimators of the dynamic models is analysed in the exchange rate models in Panopoulou \& Pittis (2004). A subclass of augmented static models or those do not involve lagged dependent variable, a restricted augmented static model, and dynamic OLS estimators are used in the estimations. The results suggest that the autoregressive distribution lag estimators perform consistently better than the dynamic OLS estimators.

An empirical study on the determinants of exchange rate volatility for Turkey was carried out for the real effective exchange rate (Kilicarslan, 2018). The study examines macroeconomic factors that affect the exchange rate of Turkey lira. Fundamental macroeconomic determination and monetary basis assume the rate of two currencies change in responding to relative prices between the two countries, trade balance between traded and non-traded sectors, and balance of payments are factors of concern in the study. Explanatory variables included in the model are foreign direct investment, gross fixed capital formation, trade openness, final government consumption, GDP, and money growth. GARCH method and Johansen cointegration analysis are used to estimate and to analyse for the real effective exchange rate volatility. Volatility, capital movements, production, and trade balance negatively affect the exchange rate volatility and uncertainty. There exists a long-run positive relationship among the real effective exchange rate and domestic investment, money supply, and trade openness and a negative long-run relationship among the real effective exchange rate and foreign direct investment, income per head, and government expenditure.

Determination of the exchange rate and policy challenge were examined in the study by Edwards \& Sahminan (2008). Similar to Central Bank of Thailand, exchange rate movements in Indonesia can be managed by some degree to support the currency if there is a sharp depreciation. Initially, the study estimated reduced-form models of the Indonesia rupiah exchange rate both nominal and real terms. The real and nominal exchange rates of rupiah have found a negative relationship with the level of country risk in the long run. The country risk is used as a proxy for default or regulatory risk. Besides, the real rupiah exchange rate has a positive relationship with the level of net foreign assets, but a negative association with the terms of trade (the effect of the relative price). The error correction mechanism is tested for the short-run and found a significant net foreign asset on the exchange rate. Theoretically, interest rate differentials affect capital flow; however, the study finds little evidence of a robust relationship between interest rate differentials and the exchange rate.

While the structural or behavioural model of the exchange rate of a currency like Thai baht is an unsolved research issue, Bouraoui \& Phisuthtiwatcharavong (2015) investigate an exchange rate of Thai baht based on the macroeconomic fundamental to explain the structure of the exchange rate. The empirical study uses monthly data 
from 2004 to 2013, and the model is based on the multiple regression OLS approach. Terms of trade, or price of exports over the price of imports, and foreign reserve are found to have a negative and a significant positive effect on the nominal exchange rate respectively. Differential interest rates of the domestic and the U.S. rate, manufacturing production index, monetary base, and government debt are found to have insignificant impacts on the behaviour of the exchange rate.

To sum up, most empirical models of the exchange rate determinants have been structured by using a variety of approaches and different methods of model estimation. The approaches of those studies are based on international balances of the countries, purchasing power parity, the monetary approach of demand for and supply of money, portfolio balance model, significant macroeconomic variables, and a random walk approach of the exchange rate.

This study aims at examining a comparative analysis of the determinants of the Thai baht exchange rate in comparison with the Asian exchange rate by using the same structure of the model. Therefore, it provides a consistent analysis of the determination of the exchange rates. The approach adopted in this study combines the random walk approach of the exchange rate, the relative prices and the law of one price under purchasing power parity approach, the interest rate under money market approach, foreign reserves as the international balance, and the external debt condition and per capita income under the macroeconomic analysis into the model of the study.

\section{The Methodology of the Study}

While there were many studies on the investigation of the relationship between exchange rate and various macroeconomic variables, empirical pieces of evidence from multiple studies were found different depending on countries in the reviews and limitation of data availability. The central hypothesis of the study is that the nominal exchange rate is a random walk series according to findings from various recent studies. Many macroeconomic variables found exhibit like a random walk, values of them overtime periods have no tendency moving back towards their mean values. As a consequence, it is not possible to forecast future values by standard methods. The estimation of the model of the exchange rate is a required modification from the standard ordinary least square estimator to avoid the spurious result. Econometrics method of time series suggests a specific type of dynamic models such as Vector Error Correction Model (VECM) to be applicable for the model estimation.

Furthermore, the study incorporates some main macroeconomic factors to be as the structural exchange rate determination model. The exchange rate is dependent on demand for and supply of foreign currencies. The macroeconomic factors related to those demand and supply sides can, therefore, describe the relative values of local currency to the foreign currency or the exchange rate. The time series analysis incorporating with the structural exchange rate of the VECM type is accordingly chosen in the estimation of the model. The model can, therefore, explain the structure or behaviour of the Thai baht why it has relatively appreciated recently even though the economic performance of Thailand has not been doing well.

The Core Model

The model of the exchange rate of Thai baht is expressed as a function written as in Equation 1 below.

$$
\text { LOXR }_{t}=f\left(R E A L D E P I N T R T_{t}, \text { RESVMONIMP }_{t}, L G D P P C_{t}, \text { EXTDEBSTGNI }_{t}\right)
$$

Where,

LOXR = Natural logarithm of Official Exchange Rate (baht/U.S. dollar)

REALDEPINTRT $=$ Real deposit interest rate

$=$ Time deposit (12 months) interest rate minuses changes in logarithmic of a consumer price index $(2010=100)$

RESVMONIMP = Total reserves in months of imports (months)

LGDPPC = Natural logarithm of per capita GDP (U.S. dollars measured in constant prices)

EXTDEBSTGNI = External debt stock as per cent of Gross National Income (per cent)

All explanatory variables included in the model are those relating to money market condition (REALDEPINTRT), international balance condition (RESVMONIMP), domestic income or purchasing power (LGDPPC), and the exogenous government policy (EXTDEBSTGNI).

The model estimation of the study consists of two parts: the vector error correction method (VECM) of time series data for the exchange rate of Thai baht and panel data method for the exchange rate of the Asian currencies.

All data set are drawn from the World Bank and Bank of Thailand for a time deposit interest rate in a missing data 
year for the period during 1979 and 2018 for Thailand. The sample period is dependent on the availability of data of all related variables.

The factors incorporated in the model are those related to the determinants as described in details as follows.

- The real deposit interest rate (REALDEPINTRT) can be an attractive power on external capital inflow. The capital flows into the country to gain a higher return when the real interest rate is higher. Note that this real interest rate, by definition, incorporates the domestic price (inflation) effect on the value of Thai baht. As a consequence, if the real deposit interest rate goes up or does the domestic price level goes down or both, it attracts higher capital inflow, and so the exchange rate will go down (the local Thai baht appreciates).

- The total foreign reserve (RESVMONIMP) accumulation is a result of a surplus balance of payment. Mundell's role of foreign reserve indicates that there is an excessive demand for Thailand exports. Once a country can increasingly earn the foreign reserve that sees in the surplus current account and balance of payment, this is a factor that leads to a stronger local currency (the Thai baht). Mathematically, the increased foreign reserve will lower the exchange rate of the Thai baht (Thai baht appreciates).

- The per capita GDP (LGDPPC) or the personal income effect can have an impact on an increase in imports or a decrease in net foreign earnings. Local people have more income so that they have higher purchasing power and higher demand for foreign goods and services. As a result, the local currency will depreciate (the exchange rate of the Thai baht per one U.S. dollar will increase).

- The external debt stock (EXTDEBSTGNI) is a significant consequence of the country's saving-investment imbalance, and so is leading to rising external debt. External debt implies long term deficit balance of payment and can reflect the government policy implementing a deficit budget. The imbalance of saving-investment gap and so an imbalance in current account cannot be too excessive in the long run because an economy can have its limited capital flow. This overspending of a country can have a result in credit confidence and local currency depreciation.

\subsection{Thailand's Exchange Rate Model}

The study estimated the model firstly by ordinary least square (OLS) method. The result of the estimation, as written in Equation 2, indicates that all explanatory variables are found to affect the exchange rate except foreign reserve significantly and are the correct sign as expected. An increase in the real interest rate appreciates the Thai baht (decreases the exchange rate). An increase in the income of people and accelerating external debt will cause a depreciation of the value of Thai baht (increases the exchange rate). However, the foreign reserve insignificantly reduces the exchange rate of Thai baht (Thai baht appreciation).

$$
\begin{array}{rlr}
\widetilde{L O X}_{t}= & 0.5287-0.0119^{* * *} R^{*} & (0.0220) \\
(\mathrm{SE}) & (0.5747) \quad(0.0068) & \\
& +0.3523^{*} \mathrm{LGDPPC}_{t}+ & 0.0048^{*} \text { EXTDEBST GNI }_{t} \\
& (0.0829) & (0.0015) \quad \ldots \ldots . .
\end{array}
$$

$$
\text { Adj } \left.\mathrm{R}^{2}=0.6027 ; \mathrm{F}(4,36)=16.1673 \text { [Prob value }=1.15 \mathrm{E}-07\right] \text {, DW-Stat }=0.3704
$$

*indicates statistically significant at no more than $1 \%, * *$ indicates statistically significant at no more than $5 \%$, *** indicates statistically significant at no more than $10 \%$

Residual diagnosis is found an autocorrelation problem consistently with the Durbin Watson Statistics. DW-Statistics is noticeable rather small. Autocorrelation function and partial autocorrelation function are in Figures $z 3$ and 34 . The result supports the use of the Vector Error Correction Method (VECM). 


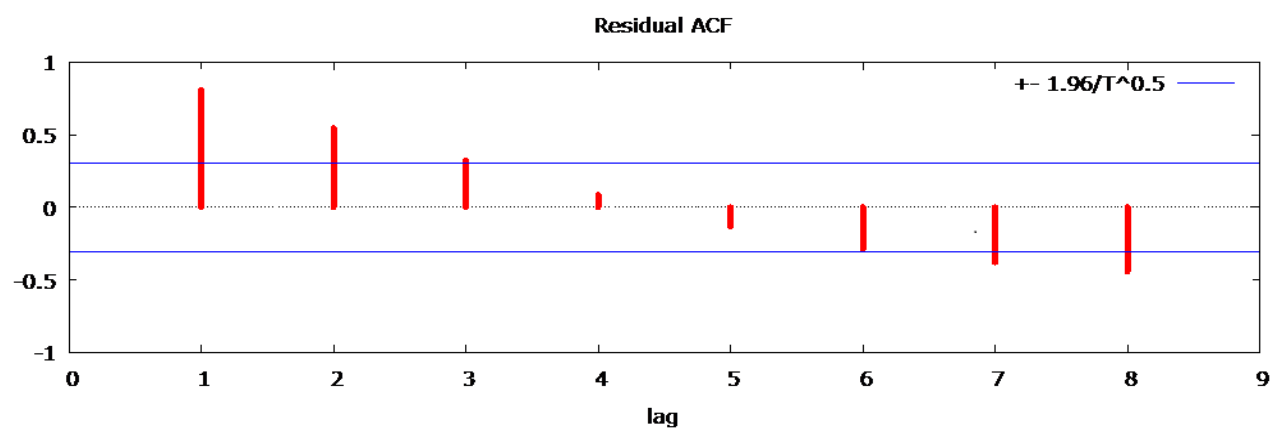

Figure 3. Autocorrelation Function (ACF) of the residuals

Source: Author's Calculation

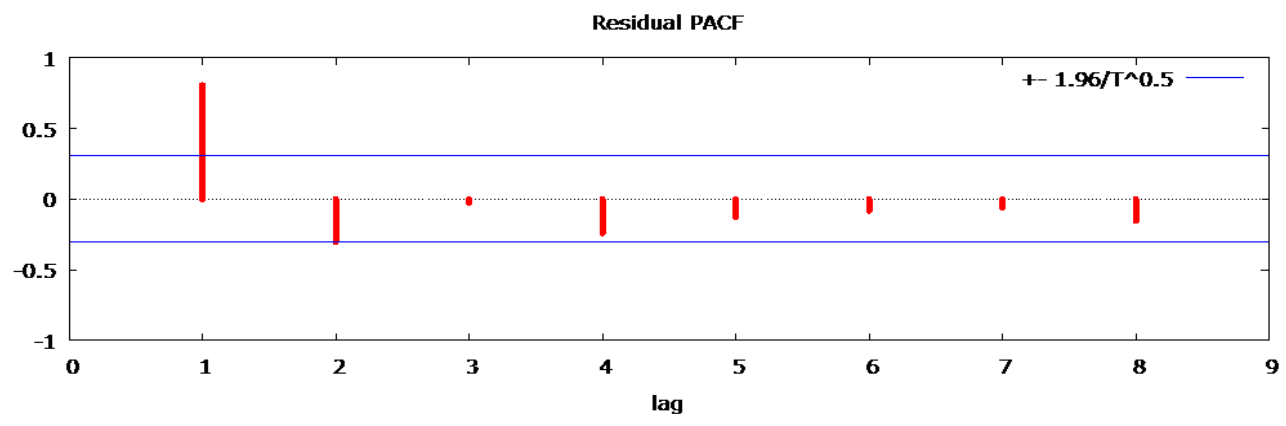

Figure 4. Partial Autocorrelation Function (PACF) of the residuals

Source: Author's Calculation

To better handle the model estimation problem above, the study estimates the model using the time series VECM. This study, therefore, employs the VECM method, which is an appropriate model for the random walk process of the exchange rate in the model. The time-series data model can be written, as shown in Equation 3.

$$
Y_{t}=\gamma+A Y_{t-1}+\mathrm{B} X_{t}+\varepsilon_{t}
$$

Where

$\mathrm{Y}=$ Vector of LOXR, REALDEPINTRT, LGDPPC, RESVMONIMP

$\mathrm{X}=$ an exogenous EXTDEBSTGNI variable

$\varepsilon=$ White noise residual vector

Equation 3 can be expressed as in Equation 4.

$$
A(L) Y_{t}=B X_{t}+\varepsilon_{t}
$$

Where

$$
\begin{gathered}
{\left[\begin{array}{c}
Y_{t} \\
Y_{t-1}
\end{array}\right]=A\left[\begin{array}{c}
Y_{t-1} \\
Y_{t-2}
\end{array}\right]+\left[\begin{array}{c}
B \\
0
\end{array}\right] X_{t}+\left[\begin{array}{c}
\varepsilon_{t} \\
0
\end{array}\right]} \\
A=\left[\begin{array}{cc}
A_{1} & A_{2} \\
I & 0
\end{array}\right]
\end{gathered}
$$

The study sets the lagged period in Equation 4 to one year due to the short length of available time-series data. The detail of the estimated model is written, as shown in Equation 5. The VECM of Equation 5 is estimated and examined for its short-run fluctuation and long-run cointegrating relations. All factors are being endogenous variables in the system except for EXTDEBSTGNI being exogenous as given by government policy.

The study firstly examines the stationarity of the variables using the Augmented Dickey-Fuller Test for Unit Root. 
All variables in the test are to be a non-stationary process (at less than 5\% significant level), or an integrated series of order one, except RESVMONIMP of which being integrated of order 0 (Table 1). Note that the exchange rate variable is to be a non-stationary or a random walk process.

Table 1. Augmented Dickey-Fuller Test for Unit Root

\begin{tabular}{lrrrrrr}
\hline & \multicolumn{2}{c}{ Level } & \multicolumn{2}{c}{ First Differencing } \\
\cline { 3 - 7 } & $\begin{array}{c}\text { With Constant, } \\
\text { Trend }\end{array}$ & $\begin{array}{c}\text { No. Lags of } \\
\text { Variable }\end{array}$ & $\begin{array}{c}\text { Tau } \\
\text { Statistics }\end{array}$ & Prob & Tau Statistics & \multicolumn{1}{c}{ Prob } \\
\hline OXR & Const. & 3 & -2.1052 & 0.2427 & -5.1369 & 0.0220 \\
REALDEPINTRT & Const., T & 1 & -3.0860 & 0.1096 & -6.6451 & $2.147 \mathrm{e}-09$ \\
RESVMONIMP & Const., T & 1 & -4.1571 & 0.0051 & -6.2232 & $2.117 \mathrm{e}-08$ \\
LGDPPV & Const. & 1 & -1.0262 & 0.7461 & -2.4230 & 0.0166 \\
EXTDEBSTGNI & Const. & 3 & -2.8183 & 0.0557 & -4.3476 & $6.047 \mathrm{e}-05$ \\
\hline
\end{tabular}

Source: Author's Calculation

Table 2. Johansen test for cointegration

\begin{tabular}{llllll}
\hline Rank & Eigenvalue & Trace Test & [p-vale] & Lmax Test & [p-value] \\
\hline 0 & 0.5299 & 59.306 & 0.0024 & 30.189 & 0.0193 \\
1 & 0.3537 & 29.117 & 0.0603 & 17.459 & 0.1564 \\
2 & 0.2262 & 11.658 & 0.1763 & 10.256 & 0.1992 \\
3 & 0.0344 & 1.4016 & 0.2365 & 1.4016 & 0.2365 \\
\hline
\end{tabular}

Lag Order = 1; Estimation Period: 1979 - 2018; Exogenous Regressor: EXTDEBSTCKGNI

Source: Author's Calculation

The VECM estimation result is as in Equation 7. The cointegrating relation which expresses the long-run equilibrium of the exchange rate model indicates that all coefficients are a statistically significant and correct sign as being expected. In the long run, equilibrium, when there is no further dynamic change in the exchange rate, increases in the real interest rate and the foreign reserve have a significant negative impact on the size of the exchange rate of Thai baht (Thai baht appreciates). On the contrary, an increase in the per capita GDP has a significant positive impact on the exchange rate of Thai baht (Thai baht depreciates). The external debt is also to cause an increase in the exchange rate (Thai baht depreciates).

$$
\begin{aligned}
& \Delta \widehat{L X R}_{t}=-0.1051^{*}+0.0031^{*} E X T D E B S T C K G N I_{t}-0.1420^{*}\left(L_{O X R_{t-1}}\right. \\
& \begin{array}{lll}
(\mathrm{SE}) \quad(0.02319) & (0.0005) \quad(0.0340)
\end{array} \\
& \left.+0.0439^{*} R^{2} A L D E P I N T R T_{t-1}+0.1624^{*} \text { RESVMONIMP }_{t-1}-0.5345^{*} \text { LGDPPC }_{t-1}\right) \\
& \text { (0.0113) (0.0361) (0.1371) }
\end{aligned}
$$

Log-likelihood for cointegrating vector $=13.9740$;

Adjusted $R^{2}=0.5083$; DW Statistics $=1.9128 ;$ Sum Squared Residual $=0.0954$

*indicates statistically significant at no more than $1 \%, * *$ indicates statistically significant at no more than $5 \%, * * *$ indicates statistically significant at no more than $10 \%$ 
The estimated size of the adjustment coefficient of the cointegration is found rather small (-0.1420); this indicates that the adjustment speed of the exchange rate to take a rather long time to get to its long-run equilibrium. In other words, this adjustment coefficient implies that it will take about 4.6 years for the short-run disequilibrium exchange rate to correctly move to its 50 per cent of the long-run equilibrium under the existing condition. Figure 5 showed Impulse Response Function (IRF) of the exchange rate (here is in the logarithm of OXR) of Thai baht to each endogenous variable.
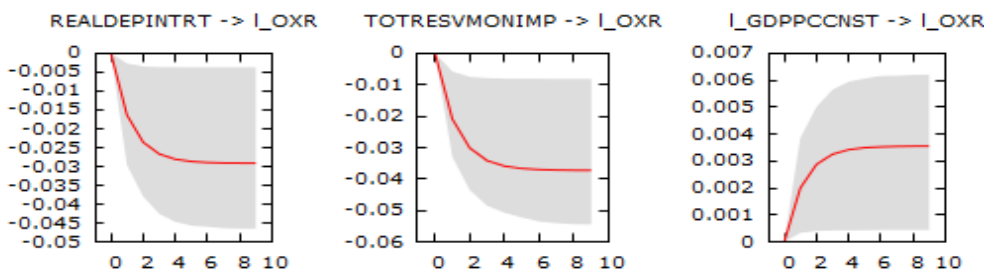

Figure 5. Impulse Response Function of LOXR

*Shaded area is the bootstrap $90 \%$ confidence interval of the point estimate

Source: Author's Calculation

The estimated model confirms that many factors are affecting the exchange rate of Thai baht. Nonetheless, the combination of the determinants is a complicated pattern and is in a term of the dynamic equation. It is, therefore, rather hard to explain the movement or the change of the exchange rate in responding to a few more changes in the macroeconomic variables. For instance, Equation 7 indicates that various components of the variables mix can determine the percentage change of the exchange rate. The combination of the past value of the exchange rate, the real interest rate, the amount of foreign reserve, the income of people, and the external debt are those factors explaining the exchange rate of Thai baht. Most of all, the empirical result confirms the hypothesis of those significant factors determining the value of the Thai baht.

To determine the movement of the exchange rate of Thai baht, the estimated Equation 7 shows the size of impacts on all factors. However, their magnitudes of the variables have different scales and standard deviations. To accurately compare the relative sizes of each component in the model, the study calculates the standardised coefficients of those factors in the model. The calculation of the standardised coefficients of the long-run cointegrating relation is, as shown in Equation 8.

$$
\beta_{j}=\frac{s_{y}}{s_{j}} \beta_{j}^{*}
$$

Where

$$
X_{j}^{*}=\frac{1}{\sqrt{N-1}}\left(\frac{X_{j i}-\overline{X j}}{s_{j}}\right)
$$

And the standardised regression is

$$
Y_{i}^{*}=\beta_{1}^{*} X_{i 1}^{*}+\cdots+\beta_{j}^{*} X_{i j}^{*}+\varepsilon_{i}^{*}
$$

The calculated standardised coefficients of variables in Equation 7 are in Table 3. The table indicates that the highest impact on the change in the exchange rate of Thai baht is from the income per capita, it follows by the foreign reserve, the real interest rate, and the external debt, respectively. 
Table 3. Standardised coefficients in Equation 7 of the exchange rate in the long-run

\begin{tabular}{lrr}
\hline & Coefficient & \multicolumn{1}{c}{$\begin{array}{c}\text { Standardised } \\
\text { Coefficient }\end{array}$} \\
\hline REALDEPINTRT & -0.0439 & -0.0068 \\
RESVMONIMP & -0.1624 & -0.0809 \\
LGDPPC & 0.5345 & 1.0119 \\
EXTDEBSTCKGNI & 0.0031 & $2.2814 \mathrm{E}-05$ \\
\hline
\end{tabular}

Source: Author's Calculation

To further investigate the effect on the change in the exchange rate of Thai baht, the estimated model of Equation 7 is used to calculate the transformation of the exchange rate from the conditions of macroeconomic factors in the years 2017 and 2018. The result of the calculation shows that the estimated exchange rate decreased (appreciated) by 4.21 per cent (or to be 32.5390 baht per U.S. dollar in 2018) which is close to the actual value of the exchange rate in 2018. Table 4 shows the real change in the exchange rate of Thai baht from 2017 to 2018 and the real macroeconomic factors' conditions.

Table 4. Factors and the exchange rate of Thai baht during 2017 and 2018

\begin{tabular}{lllll}
\hline & 2017 & 2018 & Change & Rate (\%) \\
\hline REALDEPINTRT & 0.6257 & 0.2292 & -0.40 & -63.4 \\
RESVMONIMP & 8.7850 & 7.7817 & -1.003 & -11.4 \\
GDPPC & 6128.66 & 6361.63 & 232.97 & 3.8 \\
EXTDEBSTCKGNI & 36.2301 & 35.0891 & -1.14 & -3.1 \\
OXR & $\mathbf{3 3 . 9 3 9 8}$ & $\mathbf{3 2 . 3 1 0 2}$ & $\mathbf{- 1 . 6 3}$ & $\mathbf{- 4 . 8}$ \\
\hline
\end{tabular}

Source: Author's calculation from the database

\subsection{Panel Data Estimation of Asian Exchange Rate Model}

Besides, the study examines the exchange rate model from the Asian countries panel data. The study adopts the core model in Equation 1 to be consistent with the estimation of the exchange rate of Thai baht. The panel data covers 14 countries from 2004 to 2018. The selection of countries and periods is dependent on the availability of data on all variables during the period. Nonetheless, there is no available data of external debt stock for many countries to include in the model. It is, however, noted from the earlier estimated exchange rate of the Thai baht model that the effect of the external debt is the smallest impact on the exchange rate determination (Table 3).

All the data used in the estimation is from the World Bank. Fourteen Asian countries in the estimate include Bangladesh, Cambodia, China, Indonesia, Japan, Korea, Malaysia, Myanmar, Pakistan, Philippines, Singapore, Sri Lanka, Thailand, and Vietnam for the period during 2004 and 2018. Note that data of the deposit interest rate of Japan in 2018 is not yet available; the study uses the same interest rate as in 2017 to include in the sample.

Here, the Asian exchange rate function can be written and shown as in Equation 11.

$$
O X R_{i t}=f\left(R E A L D E P I N T R T_{i t}, R_{E S V M O N I M P} \text { it }, L G D P P C P P P_{i t}\right)
$$

Where

$\mathrm{i}=1,2, \ldots, 14 ; \mathrm{t}=2004,2005, \ldots, 2018$

and LGDPPCPPP = natural logarithm of GDP per capita measured in Purchasing Power Parity to have the comparable income per capita of all countries.

Preliminarily, the study estimates the linear model in Equation 11 using the pooled OLS. The result of the estimation is, as shown in Equation 12. Surprisingly, the estimated equation revealed that the real deposit interest rate positively, but insignificantly affects the exchange rate. The foreign reserve correctly causes an appreciation of the local currencies. The countries' income per capita is also significant but surprisingly appears to create appreciated local 
currency. The result is noticeably not consistent with the estimated model of the Thai baht exchange rate, as found in Equation 7.

$$
\begin{array}{rlrl}
\widehat{L O X R}_{i t}= & 13.5223^{*}+0.0530 R E A L D E P I N T R T_{i t}- & 0.1365^{*} \text { RESVMONIMP }_{i t} \\
(\mathrm{SE}) & (2.2485) & (0.0697) \\
- & 0.8641^{*} \mathrm{LGDPPCPPP} & \\
& (0.2226)
\end{array}
$$

Adj $\mathrm{R}^{2}=0.2079 ; \mathrm{F}(3,192)=18.0600^{*}[\operatorname{Prob}=2.30 \mathrm{e}-10]$

*indicates statistically significant at no more than $1 \%$, **indicates statistically significant at no more than $5 \%$, *** indicates statistically significant at no more than $10 \%$

The study turned to focus on the panel data fixed-effect method. In general, the fixed effect panel data estimation can remove the problem of time-invariant unobserved heterogeneity similarly to the form of the first differencing model estimator. In the two time periods, the fixed-effect model can be proved to be identical to the first differencing model. As the first differencing model is to be used to solve the problem of endogeneity problem, the panel data fixed effect estimation is a preferable method (Wooldridge, 2002). The first differencing model will remove the unobserved effect in the differenced equation. The elimination of the unobserved effect can help solve the omission variable biased due to the endogeneity problem (Coursey, 2008)

F-Test for a common intercept can reject the null hypothesis so that different country fixed effect is preferable. Hausman test for random effect indicates the fixed effect model is preferred. The study estimates for the fixed effect model. The result is as Equation 13. The country-specific effect is as Table 5.

$$
\begin{array}{rlrl}
\widehat{L O X R}_{i t}= & -7.0309^{*}- & 0.0972^{*} R E A L D E P I N T R T_{i t}- & 0.1464^{*} R E S V M O N I M P_{i t} \\
(\mathrm{SE}) & (2.4292) & (0.0333) & (0.0269) \\
& +1.4515^{*} \mathrm{LGDPPCPPP} & \\
& (0.2587)
\end{array}
$$

Within $\mathrm{R}^{2}=0.3175, \operatorname{LSDV} \mathrm{R}^{2}=0.9574, \operatorname{LSDV} \mathrm{F}(16,179)=251.1956, \mathrm{D} . \mathrm{W}$. Stat $=0.4240, \mathrm{~F}(3,179)=27.7602$ $[\mathrm{P}$-value $=8.64805 \mathrm{E}-015]$

Test for common intercept: $\mathrm{F}(13,179)=238.0920$ [P-vale $=1.80486 \mathrm{E}-105]$

Hausman test: $\chi^{2}(3)=12.0185[\mathrm{P}$-value $=0.0073]$

*indicates statistically significant at no more than $1 \%$, **indicates statistically significant at no more than $5 \%$, *** indicates statistically significant at no more than $10 \%$.

Table 5. Country-specific effect

\begin{tabular}{ccccccc}
\hline BGD & KHM & CHN & IDN & JPN & KOR & MYS \\
\hline-5.7708 & -2.3101 & -8.5806 & -2.3431 & -8.3208 & -6.6992 & -12.1045 \\
\hline MMR & PAK & PHL & LKA & SGP & THA & VNM \\
\hline-5.8149 & -6.5621 & -7.2295 & -15.1748 & -7.1361 & -9.0910 & -1.2954 \\
\hline
\end{tabular}

Source: Author's Calculation

*BGD $=$ Bangladesh, $\mathrm{KHM}=$ Cambodia, $\mathrm{CHN}=$ China, $\mathrm{IDN}=$ Indonesia, JPN $=$ Japan, $\mathrm{KOR}=$ Korea, MYS $=$ Malaysia, MMR $=$ Myanmar, PAK $=$ Pakistan, $\mathrm{PHL}=$ Philippines, LKA $=$ Sri Lanka, $\mathrm{SGP}=$ Singapore, THA $=$ Thailand, and VNM = Vietnam

From Table 5, the country-specific effect of Thailand is one of a few countries that have relatively small values. This finding implies that the exchange rate of Thai baht is generally on average, relatively lower than many other local currencies' exchange rate.

To examine the relative size of impacts on the exchange rates among those three explanatory variables, the calculated standardised coefficients of those variables are in Table 6. Similarly to the case of Thailand, the estimated Asian 
exchange rate model indicates the highest impact is from the income per capita on the change in the exchange rate. It follows by the foreign reserve and the real deposit interest rate, respectively. However, the relative sizes of the impacts of the international reserve and the real interest rate on the appreciation of the local Asian currencies are closer to each other than both of them on the Thai baht exchange rate model. In other words, the foreign reserve has a relatively higher impact on the appreciation of the exchange rate than that of the real interest rate for Thailand when compared to the Asian currencies. The finding of the strong impact of the foreign reserve is consistent with the statistics. The foreign reserves of Thailand were stable at about 2-3 months of the imports before the Asian financial crisis in 1997-1998; it has been steady at around 5-7 months of imports since after the financial crisis.

Table 6. The standardised coefficients of Equation 13 of $\Delta$ LOXR for the Asian exchange rate model

\begin{tabular}{lrr}
\hline & Coefficient & \multicolumn{1}{c}{$\begin{array}{c}\text { Standardised } \\
\text { Coefficient }\end{array}$} \\
\hline REALDEPINTRT & -0.0972 & -0.0011 \\
RESVMONIMP & -0.1464 & -0.0014 \\
LGDPPC & 1.4515 & 0.1313 \\
\hline
\end{tabular}

Source: Author's Calculation

\section{Conclusion}

The exchange rate is a crucial macroeconomic variable. It is an essential factor for economic development, especially in many developing countries as their economies heavily rely on exports as a source of growth. It is interesting to empirically investigate in details of what are the significant factors that determine the value of the local currency.

Several factors can influence the value of the local currency. The exchange rate of the local currency is determined by its demand for and supply of foreign currency. Therefore, those factors which increase the demand for dollar increase the value of the dollar. Conversely, if a country earns more dollars, so the value of the dollar decreases.

The model of exchange rate behaviour is well acknowledged to be uncertain research issues. It is essential to empirically investigate in details of what are the significant factors that determine the value of Thai baht. The central hypothesis of the study is that the nominal exchange rate is a random walk series according to findings from various recent studies. Econometrics method of time series suggests a specific type of dynamic models such as Vector Error Correction Model (VECM) to be applicable for the model estimation. Furthermore, the study incorporates some main macroeconomic factors to be as the structural model of exchange rate determination. The research consists of 2 parts: time series analysis of the VECM for Thai baht exchange rate and panel data estimation for the Asian exchange rate determination.

The exchange rate variable of Thai baht is found to be a random walk process. The cointegrating relation which expresses the long-run equilibrium of the exchange rate indicates that all coefficients are a statistically significant and correct sign. In the long-run equilibrium, increases in the real interest rate and the foreign reserve have substantial adverse effects on the exchange rate of Thai baht (Thai baht appreciates). Reversely, an increase in the income per capita has a significant positive impact on the exchange rate of Thai baht (Thai baht depreciates). The external debt is to cause an increase in the exchange rate (Thai baht depreciates). The standardised coefficients of variables show that the most significant impact on the change in the exchange rate of Thai baht is the income per capita, it follows by the foreign reserve, the real interest rate, and the external debt, respectively.

The estimated VECM model of Thai baht is used to calculate the change of exchange rate from the real conditions of macroeconomic factors in the years 2017 and 2018. The simulation result shows that the estimated exchange rate decreases (appreciates) by 4.21 per cent (to be 32.5390 baht per U.S. dollar in 2018). The result was close to the actual exchange rate value in 2018 .

Furthermore, the study estimates the exchange rate model for Asian currencies. The study adopts the same behavioural model to be consistent with the model of Thai baht exchange rate. The panel data covers 14 Asian countries from 2004 to 2018 . There is no available data of external debt stock for many countries to include in the model. However, the external debt stock is the smallest impact on the exchange rate determination found in the Thai baht exchange rate model. 
Similarly to the Thailand case, the estimated Asian exchange rate model indicates the highest impact is from the income per capita on the change in the exchange rate. It follows by the foreign reserve and the real deposit interest rate, respectively. Even so, the international reserve has a relatively more substantial effect than that of the real interest rate for Thailand when compared to the Asian countries.

It is interesting to note that Thailand has increasingly accumulated foreign reserves over the decades. The data shows that the foreign reserves are about 2-3 months of the imports before the Asian financial crisis in 1997-1998; it has been steady at around 5-7 months of imports in the recent years after the crisis. Moreover, the panel data analysis shows Thailand has a relatively sizeable country-specific effect in terms of appreciating currencies. From the findings, the relatively more substantial country-specific fact in terms of currency appreciation and the accumulated massive amounts of the foreign reserve of Thailand can indicate the relatively strong Thai baht by its structure. From the findings of the study, income growth acceleration, promotion of Thailand direct investment abroad, and Thailand capital outflow can help boost the depreciation of Thai baht.

\section{References}

Abhyankar, A. L. S., \& Valente, G. (2005). Exchange rates and fundamentals: Evidence on the economic value of predictability. Journal of International Economics, 66(2), 325-348. https://doi.org/10.1016/j.jinteco.2004.09.003

Balassa, B. (1964). The Purchasing-Power Parity doctrine: A reappraisal. Journal of Political Economy, 36, 309-412.

Bouraoui, T., \& Phisuthtiwatcharavong, A. (2015). On the determinants of the THB/USD exchange rate. Procedia Economics and Finance, 30, 137-145. https://doi.org/10.1016/S2212-5671(15)01277-0

Cheung, Y. W., Menzie D. C., \& Pascual, A. G. (2005). Empirical exchange rate models of the nineties: Are any fit to survive?. Journal of International Money and Finance, 24(7), 1150-1175. https://doi.org/10.1016/j.jimonfin.2005.08.002

Chinn, D. M. (2003). Explaining exchange rate behavior (NBER Reporter: Research Summary, Spring). Retrieved from https://admin.nber.org/reporter/spring03/explaininge.html

CNBC. (2019). Thailand's currency keeps getting stronger and that's sparking concerns, 30 July 2019. Retrieved from https://www.cnbc.com/2019/07/31/thai-baht-strength-sparks-concerns-with-thailand-economy-slowing.html

Coursey, D. H. (2008). Confirmatory factor analysis: A practical introduction. In G. J. Miller, \& K. Yang (Eds.), Handbook of Research Methods in Public Administration (pp. 565-574). New York: Taylor \& Francis Group.

Cumby, R. E., \& Obstfeld, M. (1984). International interest rate and price level linkages under flexible exchange rates: A review of recent evidence. In J. F. O. Bilson, \& R. C. Marston (Eds.), Exchange Rate Theory and Practice (pp. 121-152). Chicago: University of Chicago Press. Retrieved from https://www.nber.org/chapters/c6832.pdf

Del Castillo, G. (2002). Determination of nominal exchange rates: A survey of the literature. In M. S. Khan, S. M. Nsouli, \& C. H. Wong (Eds.), Macroeconomic Management: Programs and Policies (pp. 257-306). Washington, D.C.: IMF Institute.

Dornbusch, R. (1976). Expectations and exchange rate dynamics. Journal of Political Economy, 84(6), 1161-1176.

Edwards, K., \& Sahminan, S. (2008). Exchange rate movements in Indonesia: Determinants, effects, and policy challenges. Working Paper No. 25/2008. Reserve Bank of Australia and Bank Indonesia. Retrieved from http://publication-bi.org/repec/idn/wpaper/WP252008.pdf

Frenkel, J. A. (1981). The collapse of Purchasing Power Parities during the 1970s. European Economic Review, 7 , 145-165. https://doi.org/10.1016/0014-2921(81)90055-6

Frenkel, J. A., \& Mussa, M. L. (1985). Assets markets, exchange rates and the balance of payments. In R. Jones, \& P. B. Kennen (Eds.), Handbook of International Economics (Vol 2, pp. 679-747). Elsevier.

Froot, K. A., \& Rogoff, K. (1994). Perspectives on PPP and long-run real exchange rates. Working Paper No. 4952. National Bureau of Economic Research. Retrieved from tohttps://scholar.harvard.edu/files/rogoff/files/perspectives_on_ppp_and_long-run_real_exchange_rates.pdf

Hwang, J. K. (2003). The Dornbusch-Frankel exchange rate model and cointegration: Evidence from the Yen-Dollar. Journal of International Business and Economics. Retrieved from https://papers.ssrn.com/sol3/papers.cfm?abstract_id=1713575 
Isard, P. (1995). Exchange rate economics. Cambridge: Cambridge University Press.

Killicarslan, Z. (2018). Determinants of exchange rate volatility: Empirical evidence for Turkey. Journal of Economics, Finance and Accounting, 5(2), 204-213. https://doi.org/10.17261/Pressacademia.2018.825

Klyuev, V., \& Dao, T. N. (2016). Evolution of exchange rate behavior in the ASEAN-5 countries. Working Paper No. 16/165. International Monetary Fund. from https://www.imf.org/en/Publications/WP/Issues/2016/12/31/Evolution-of-Exchange-Rate-Behavior-in-the-ASE AN-5-Countries-44174

Markin, A. J. (1984). The main determinants of the exchange rate. Economic Analysis and Policy, 14(1), 20-29. https://doi.org/10.1016/S0313-5926(84)50002-2

Meese, R. A., \& Rogoff, K. (1983). Empirical exchange rate models of the seventies: Do they fit out of sample?. Journal of International Economics, 14, 3-24.

Mundell, R. A. (1968). International Economics. New York: Macmillan, Chapter 18, pp. 250-271. Retrieved from http://www.columbia.edu/ ram15/ie/ie-18.html

Panopoulou, E., \& Pittis, N. (2004). A comparison of autoregressive distributed lag and dynamic OLS cointegration estimators in the case of a serially correlated cointegration error. Econometrics Journal, 7(2), 585-617. https://doi.org/10.1111/j.1368-423X.2004.00145.x

Salim, A., \& Shi, K. (2019). A cointegration of the exchange rate and macroeconomic fundamentals: The case of the Indonesian rupiah vis-à-vis currencies of primary trade partners. Journal of Risk and Financial Management, 12(2), 87. https://doi.org/10.3390/jrfm12020087

Tease, W. (1990). The balance of payments in the 1980s. Research Discussion Paper No. 9003. Reserve Bank of Australia. Retrieved from https://www.rba.gov.au/publications/rdp/1990/pdf/rdp9003.pdf

Wooldridge, J. M. (2002). Econometric analysis of cross section and panel data. Cambridge: The Massachusetts Institute of Technology Press.

\section{Copyrights}

Copyright for this article is retained by the author(s), with first publication rights granted to the journal.

This is an open-access article distributed under the terms and conditions of the Creative Commons Attribution license (http://creativecommons.org/licenses/by/4.0/). 